\title{
Horizontale natrekking bij ondergrondse gangen
}

\author{
Dr. K.K.E.C.T. Swinnen*
}

\section{Inleiding}

Cuius est solum, eius est usque ad coelum et ad inferos. Van de hemel tot de hel, met die woorden werden in het verleden vaak de uitgestrektheid en alomvattendheid van het eigendomsrecht op een stuk grond omschreven. $\mathrm{Al}$ wat zich boven of onder de grond bevindt, behoort, op bepaalde uitzonderingen na, toe aan de grondeigenaar of valt binnen diens eigenaarsbevoegdheden. Ook vandaag nog zijn de rechten van een grondeigenaar niet beperkt tot alleen de grond en strekken die zich onder meer ook uit tot de onderliggende aardlagen, het water dat zich op de grond bevindt en de duurzaam met de grond verenigde gebouwen en werken (art. 5:20 lid 1 jo. art. 5:21 lid 1 BW).

Een gebouw of werk stopt echter niet altijd bij de grenzen van een gronderf. Zo kunnen gebouwen of werken die werden opgericht op of onder een gronderf dat later wordt gesplitst (bijvoorbeeld bij verkoop van een gedeelte van het gronderf of verdeling onder erfgenamen), zich vandaag op of onder meerdere gronderven bevinden. Denk bijvoorbeeld aan een kelder onder meerdere gronderven of een schuur die op meerdere gronderven staat. Om te vermijden dat dergelijke gebouwen of werken ingevolge de regel van art. 5:20 lid $1 \mathrm{BW}$ juridisch worden gesplitst, voorziet het slot van de voornoemde regel in de figuur van de horizontale natrekking: het voornaamste gedeelte van het gebouw of werk trekt dan het andere gedeelte na, waardoor zij juridisch samenblijven.

De concrete toepassing van horizontale natrekking blijkt in de praktijk echter niet altijd eenvoudig te zijn. Dat is in het bijzonder het geval in, wat ik zou willen noemen, situaties van onbeslechte horizontale natrekking. Dat zijn situaties waarin meerdere gedeelten van een grensoverschrijdend gebouw of werk als het voornaamste gedeelte zouden kunnen worden aangemerkt. Welk gedeelte trekt dan het gehele gebouw of werk horizontaal na? Het antwoord op die vraag is geenszins zonder belang, omdat het voor de betrokken eigenaren beslist over eigendomsverlies dan wel eigendomsuitbreiding.

In dit artikel wordt, met bijzondere aandacht voor ondergrondse gangen, stilgestaan bij deze problematiek. Daarbij wordt ook ingegaan op de door sommige auteurs verdedigde zienswijze dat mede-eigendom van het grensoverschrijdende

Dr. K.K.E.C.T. Swinnen is universitair docent goederen- en insolventierecht aan de Erasmus School of Law. gebouw of werk een oplossing kan zijn. Eveneens, en in de eerste plaats, worden in dit artikel de theorie en basisprincipes inzake horizontale natrekking uiteengezet. Daarbij wordt steeds teruggekoppeld naar een vonnis van de rechtbank Limburg van 7 februari $2018^{1}$ over horizontale natrekking bij een ondergronds gangenstelsel, dat de aanleiding voor het schrijven van dit artikel heeft gevormd en om meerdere redenen interessant kan worden genoemd. Zo biedt het vonnis de mogelijkheid om de theorie en basisprincipes inzake horizontale natrekking nog eens scherp te stellen en vormen de specifieke feiten van het onderliggende geschil de perfecte opstap naar een nadere bespreking van de problematiek van situaties van onbeslechte horizontale natrekking.

Omdat het voornoemde vonnis van de rechtbank Limburg als een rode draad door het artikel loopt, zet ik in de navolgende paragraaf (beknopt) de feiten die aan dit vonnis ten grondslag lagen uiteen.

\section{De aanleiding: $\mathrm{Rb}$. Limburg 7 februari 2018}

Door mergelwinning is onder drie gronderven, die in het vonnis worden aangeduid als perceel 1 , perceel 2 en perceel 3 , een aaneengesloten gangenstelsel ontstaan. Directe toegang tot dit gangenstelsel is mogelijk via perceel 1 en perceel 3. Indirect kunnen de gangen ook worden bereikt via een later gegraven gang die uitkomt in de gangen onder perceel 2 en vertrekt in een ander (onder andere gronderven gelegen) gangenstelsel. In 1990 heeft de gemeente als eigenaar van perceel 2 daarop een erfpachtrecht toegestaan ten behoeve van de Stichting, waarin ook de gangen onder perceel 2 werden opgenomen. Later heeft de Stichting met J \& R Activity B.V. (hierna: J\&R), die eigenaar is van perceel 1 , een huurovereenkomst gesloten op grond waarvan een gedeelte van de gangen onder perceel 2 aan $\mathrm{J} \& \mathrm{R}$ wordt verhuurd.

Het geschil ontstaat wanneer J\&R besluit niet langer de huurprijs te betalen en, met een beroep op wilsgebreken, de huurovereenkomst vernietigt. Daarbij betoogt J\&R dat de Stichting geen erfpachter is van de verhuurde gangen onder perceel 2, waardoor zij die ook niet kan verhuren, en dat J\&R, als eigenaar van perceel 1 , op grond van horizontale natrekking eigenaar is van die gangen. Voor de rechtbank Limburg vordert J\&R onder meer een verklaring voor recht dat zij, subsidi-

1. Rb. Limburg 7 februari 2018, ECLI:NL:RBLIM:2018:1142. 
air de eigenaar van perceel 3, die als mede-eiser optreedt, en meer subsidiair zij en de eigenaar van perceel 3 gezamenlijk, eigenaar zijn van de gangen onder perceel 2 op grond van horizontale natrekking. De rechtbank wijst die vordering toe en verklaart dat de gangen onder perceel 2 door horizontale natrekking aan J\&R (zijnde de eigenaar van perceel 1) toebehoren.

Daar het onderhavige artikel specifiek over horizontale natrekking gaat, beperkt de bespreking van het vonnis van de rechtbank Limburg en van de daaraan ten grondslag liggende feiten zich hier tot het tussen partijen gerezen geschil omtrent de eigendom van de gangen onder perceel $2 .^{2}$ In dit artikel zal op meerdere plaatsen echter nog dieper worden ingegaan op voor de daar gevoerde bespreking relevante feiten en onderdelen van het vonnis.

\section{Verticale natrekking als basisregel}

\subsection{Art. 5:20 lid 1 BW}

Een gebouw of werk dat duurzaam met de grond is verenigd, is eigendom van de grondeigenaar. Die regel, die is neergelegd in art. 5:20 lid 1 sub e BW in samenhang met de aanhef van art. 5:20 lid $1 \mathrm{BW}$, vormt de basisregel inzake de eigendom van duurzaam met de grond verenigde gebouwen en werken en wordt 'verticale natrekking' genoemd. Wat betreft het vereiste van een duurzame vereniging heeft de Hoge Raad geoordeeld dat daarvan sprake kan zijn wanneer het gebouw of werk 'naar aard en inrichting bestemd is om duurzaam ter plaatse te blijven'. ${ }^{3}$ Ondergrondse gangen voldoen in de regel aan dit vereiste, hetgeen betekent dat zij in beginsel toebehoren aan de eigenaar van de grond waarin zij zich bevinden.

\subsection{Toepassing door de rechtbank Limburg}

De rechtbank Limburg begint haar beoordeling van het geschil met het uiteenzetten van de regels inzake verticale natrekking, waarbij zij verduidelijkt dat duurzaam met de grond verenigde gebouwen en werken, die zij gezamenlijk 'bouwwerken' noemt, bestanddeel zijn van de grond in de zin van art. 3:3 BW. ${ }^{4}$ Door dit te verduidelijken heeft de rechtbank - al dan niet bewust - een standpunt ingenomen in een debat dat een aantal jaren geleden nog menig goederenrechtelijke pen in beweging heeft gebracht. ${ }^{5}$ Centraal in dit debat stond de vraag of bouwwerken die duurzaam met de grond zijn verenigd, en als gevolg daarvan toebehoren aan de grondeigenaar, bestanddeel zijn van de grond dan wel als een zelf-

2. Voor een bespreking van andere onderdelen van het vonnis kan worden verwezen naar de annotatie van Visser in TvZ 2018, p. 26-28.

3. Zie specifiek m.b.t. art. 5:20 lid 1 sub e BW HR 25 oktober 2002, ECLI:NL:PHR:2002:AE6999 (Grafzerken-arrest). M.b.t. art. 3:3 lid 1 $\mathrm{BW}$, waarin de wetgever hetzelfde criterium van een duurzame vereniging met de grond heeft gebruikt, zie o.m. HR 27 september 2013, ECLI:NL:HR:2013:CA0813; HR 17 november 2006, ECLI:NL:HR: 2006:AZ2377; HR 24 juni 2005, ECLI:NL:HR:2005:AQ7093; HR 31 oktober 1997, ECLI:NL:HR:1997:ZC2478 (Portacabin-arrest), r.o. 3.3 .

4. Rb. Limburg 7 februari 2018, ECLI:NL:RBLIM:2018:1142, r.o. 4.2.1.

5. Zie de auteurs genoemd in noot 6 . standige zaak moeten worden aangemerkt. De rechtbank kiest dus partij voor de eerste visie. Het bestaan van die vraag is een direct gevolg van het feit dat de wetgever in art. 5:20 lid $1 \mathrm{sub}$ e BW een ander criterium heeft gehanteerd, te weten het bestaan van een duurzame vereniging met de grond, dan in het specifiek aan bestanddeelvorming gewijde art. 3:4 BW, dat de verkeersopvatting (lid 1) en het bestaan van een niet zonder beschadiging van betekenis te verbreken fysieke verbinding (lid 2) als criteria bevat. Moet daaruit worden afgeleid dat de in art. 5:20 lid 1 sub e BW genoemde duurzaam met de grond verenigde gebouwen of werken geen bestanddelen zijn?

Dit artikel is niet de plaats om dieper op deze discussie in te gaan of daarin een standpunt in te nemen. Dat is met het oog op het aan de rechtbank Limburg voorgelegde geschil ook niet nodig, omdat de gangen die daarin centraal staan mijns inziens sowieso bestanddelen zijn, namelijk op grond van art. 3:4 BW. Meer specifiek zijn zij bestanddelen op grond van art. 3:4 lid 2 $\mathrm{BW}$, omdat de gangen en de grond niet van elkaar kunnen worden gescheiden zonder beschadiging van betekenis toe te brengen aan de gangen. Het wezenlijke van een (ondergrondse) gang is immers dat die bestaat uit een uitsparing of lege ruimte in de grond, waardoor die niet zonder de grond kan bestaan. Bijgevolg kunnen beide onmogelijk van elkaar worden gescheiden zonder het einde van de gang tot gevolg te hebben en dus een beschadiging van betekenis te veroorzaken. Desalniettemin is het nuttig om in dit artikel op te merken dat de rechtbank duurzaam met de grond verenigde bouwwerken uitdrukkelijk als bestanddelen heeft aangemerkt, omdat zij daar, zo zal hieronder blijken, niet geheel consequent mee is omgesprongen in haar vonnis.

\section{Horizontale natrekking als uitzondering op de basisregel}

Het slot van art. 5:20 lid 1 sub e BW bevat met de woorden 'voor zover ze geen bestanddeel zijn van eens anders onroerende zaak' een uitzondering op de hierboven besproken basisregel van verticale natrekking. Die uitzondering moet zo worden begrepen, dat een duurzaam met de grond verbonden gebouw

6. Voor een ontkennend antwoord op deze vraag, zie o.m. H.W. Heyman \& S.E. Bartels, Vastgoedtransacties. Koop, Den Haag: Boom Juridische uitgevers 2012, p. 48; K. Hoofs, Doorbreking van de natrekking in rechtsvergelijkend perspectief, Nijmegen: Wolf Legal Publishers 2012, p. 89; H.J. Snijders \& E.B. Rank-Berenschot, Goederenrecht (Studiereeks Burgerlijk Recht 2), Deventer: Wolters Kluwer 2017, p. 28; L.P.W. van Vliet, Natrekking door onroerende zaken. Bespreking van het proefschrift van mr. P.J. van der Plank, MvV 2017, p. 26. Zie echter in tegengestelde zin o.m. Th.F. de Jong, De structuur van het goederenrecht. Over het afschaffen van het begrip van de onlichamelijke zaak, het onderscheid tussen rechten en hun voorwerpen en een opening in het systeem, Deventer: Kluwer 2006, p. 1025-1026; H.D. Ploeger, Horizontale splitsing van eigendom, Deventer: Kluwer 1997, p. 119-127; G.E. van Maanen, in: W.H.M. Reehuis \& A.H.T. Heisterkamp, Goederenrecht (Pitlo, deel 3), Deventer: Wolters Kluwer 2019, p. 460; J.E. Wichers, Natrekking, vermenging en zaaksvorming. Opmerkingen bij de algemene regeling voor roerende zaken in het Burgerlijk Wetboek, Deventer: Kluwer 2012, p. 68; E.C.M. Wolfert, Bestanddeel of zaak? Over het onderscheid en de samenhang tussen de artikelen 3:4 en 5:20 BW (II), WPNR 2003, afl. 6523, p. 280-282. 
of werk niet toebehoort aan de grondeigenaar waarin of waarop zich dit bevindt wanneer het een bestanddeel is van de onroerende zaak van een ander; het gebouw of werk behoort dan toe aan de eigenaar van die laatste onroerende zaak. Deze eigendomstoewijzing, die 'horizontale natrekking' wordt genoemd, prevaleert boven de verticale natrekking, zoals de rechtbank Limburg ook uitdrukkelijk aangeeft in haar vonnis. $^{7}$

Bij de beoordeling van het al dan niet plaatsgehad hebben van horizontale natrekking stelt de rechtbank Limburg vast dat de gangen onder de drie in het geding aan de orde zijnde percelen één gangenstelstel en 'daarmee één zaak' vormen. ${ }^{8}$ Dit steunt zij op het feit dat de gangen onder de verschillende gronderven met elkaar zijn verbonden en doorlopen, waardoor het mogelijk is om van het ene naar het andere gronderf te lopen. Aldus zijn, volgens de rechtbank, de gangen onder perceel 2 bestanddeel van een andere onroerende zaak, namelijk het gehele gangenstelsel, en moet, zo geeft de rechtbank uitdrukkelijk aan, ${ }^{9}$ de vraag worden beantwoord wie eigenaar is van dat gangenstelsel. De rechtbank herformuleert de aan haar voorgelegde vraag of de gangen onder perceel 2 verticaal (door perceel 2) dan wel horizontaal (door perceel 1 of perceel 3) worden nagetrokken dus tot de vraag wie eigenaar is van het gehele gangenstelsel.

Het oordeel van de rechtbank dat het gangenstelsel 'één zaak' vormt, is vanuit theoretisch oogpunt echter niet volledig zuiver. Eerder in dit artikel heb ik immers betoogd dat de gangen onder de verscheidene gronderven ingevolge art. 3:4 lid 2 BW bestanddeel zijn van de gronderven waaronder zij zich bevinden en, belangrijker nog, dat ook de rechtbank Limburg de kwalificatie als bestanddeel aanneemt. Een onvermijdelijk gevolg daarvan is dat de gangen geen zaken (in de zin van art. 3:2 BW) zijn, daar iets niet tegelijkertijd een zaak én een bestanddeel kan zijn. Bijgevolg kunnen zij niet fungeren als 'eens anders onroerende zaak' zoals bedoeld in art. 5:20 lid 1 sub e BW. Dat zou enkel anders zijn geweest indien zij goederenrechtelijk van de grond waren losgemaakt door middel van een opstalrecht. Daarvan is in deze zaak echter geen sprake. De enige objecten die in casu als 'eens anders onroerende zaak' kunnen fungeren ten aanzien van de gangen onder perceel 2, zijn de percelen 1 en 3, die als gronderven wel zaken zijn. Opdat er van horizontale natrekking ten behoeve van één van deze percelen sprake zou kunnen zijn, moeten de gangen onder perceel 2 kunnen worden aangemerkt als bestanddelen van één van beide percelen. De gangen vormen dan, vanuit theoretisch oogpunt, een bestanddeel van de (eenheids)zaak bestaande uit (a) perceel 1 of perceel 3, (b) de daarin uitgegraven gangen en (c) de gangen onder perceel 2. Die (eenheids)zaak wordt goederenrechtelijk echter gelijkgesteld met haar hoofdbestanddeel, zijnde perceel 1 of perceel 3 .

7. Rb. Limburg 7 februari 2018, ECLI:NL:RBLIM:2018:1142, r.o. 4.2.3 in fine.

8. Rb. Limburg 7 februari 2018, ECLI:NL:RBLIM:2018:1142, r.o. 4.2.6.

9. Rb. Limburg 7 februari 2018, ECLI:NL:RBLIM:2018:1142, r.o. 4.2.6.

\section{Horizontale natrekking bij ondergrondse gangen}

\subsection{Art. 3:4 BW en de verkeersopvatting}

De beoordeling of de gangen onder perceel 2 bestanddeel zijn van een van de aanpalende gronderven, dient te gebeuren aan de hand van art. 3:4 BW, dat aangeeft wanneer iets een bestanddeel van een zaak is. Art. 3:4 BW bevat, zoals reeds werd opgemerkt, twee criteria: de verkeersopvatting (lid 1) en het bestaan van een fysieke verbinding die niet kan worden verbroken zonder schade van betekenis toe te brengen aan een van de verbonden zaken (lid 2). Overwegend wordt aangenomen dat deze criteria nevengeschikte criteria zijn en dat het bijgevolg volstaat voor bestanddeelvorming dat één daarvan is vervuld. ${ }^{10}$

\subsection{Nadere invulling van de verkeersopvatting door de Hoge Raad}

In het BW wordt niet verduidelijkt wanneer iets naar verkeersopvatting een bestanddeel is van een zaak. De Hoge Raad heeft deze leemte (deels) opgevuld in de arresten Dépex ${ }^{11}$ en Prorail. ${ }^{12}$ In het eerste arrest heeft de Hoge Raad geoordeeld dat wanneer een gebouw en apparatuur in constructief opzicht specifiek op elkaar zijn afgestemd', ${ }^{13}$ er een aanwijzing voorligt voor het feit dat deze zaken naar verkeersopvatting als één zaak moeten worden gezien. Hetzelfde geldt, aldus de Hoge Raad, wanneer het gebouw uit een oogpunt van geschiktheid als fabrieksgebouw zonder de apparatuur als onvoltooid moet worden beschouwd. Aan de criteria van constructieve afstemming en onvoltooidheid heeft de Hoge Raad in het Prorail-arrest nog toegevoegd dat 'de omstandigheid dat een zaak ten opzichte van een andere zaak een tijdelijke hulpfunctie vervult en bestemd is om daarna te worden verwijderd, in het algemeen een aanwijzing oplevert ${ }^{\text {'14 }}$ voor het feit dat die zaak naar verkeersopvatting geen bestanddeel is.

Deze criteria zijn, zoals de Hoge Raad ook zelf uitdrukkelijk aangeeft, slechts aanwijzingen voor het bestaan van een positieve verkeersopvatting. Steeds, zo heeft de Hoge Raad in een recent arrest nog herhaald, ${ }^{15}$ moet de vraag of in een bepaald

10. Zie o.m. Heyman \& Bartels 2012, p. 37; W.H.M. Reehuis \& A.H.T. Heisterkamp, Goederenrecht (Pitlo, deel 3), Deventer: Wolters Kluwer 2019, p. 8; Snijders \& Rank-Berenschot 2017, p. 28; Wichers 2002, p. 77-78. Zie echter in tegengestelde zin o.m. P.J. van der Plank, Natrekking door onroerende zaken, Deventer: Wolters Kluwer 2016, p. 236; P.J. van der Plank, De verkeersopvatting als leidend criterium voor bestanddeelvorming in de zin van art. 3:4 BW, WPNR 2015, afl. 7086, p. 1035-1037; Wolfert 2003, p. 283.

11. HR 15 november 1991, ECLI:NL:HR:1991:ZC0412 (Dépex/Bergel). Zie recenter ook HR 7 december 2018, ECLI:NL:HR:2018:2256; HR 6 december 2012, ECLI:NL:HR:2012:BX7474.

12. HR 6 december 2012, ECLI:NL:HR:2012:BX7474 (Prorail/Rijswijk Wonen).

13. HR 15 november 1991, ECLI:NL:HR:1991:ZC0412 (Dépex/Bergel), r.o. 3.7 .

14. HR 6 december 2012, ECLI:NL:HR:2012:BX7474 (Prorail/Rijswijk Wonen), r.o. 3.5.2.

15. HR 7 december 2018, ECLI:NL:HR:2018:2256, r.o. 3.4.2. Daarin verwijst de Hoge Raad naar HR 6 december 2012, ECLI:NL:HR: 2012:BX7474 (Prorail/Rijswijk Wonen). 
geval naar verkeersopvatting sprake is van een bestanddeel in het licht van alle omstandigheden van het geval beoordeeld worden'. Dit betekent dat de door de Hoge Raad geformuleerde aanwijzingen tegengesproken kunnen worden door het geheel van de omstandigheden van de zaak. Ook is het niet zo dat de Hoge Raad in de hierboven genoemde arresten een limitatieve lijst van aanwijzingen voor een positieve verkeersopvatting heeft ingesteld; ook andere omstandigheden kunnen een aanwijzing vormen voor het feit dat iets naar verkeersopvatting een bestanddeel is. Dat is niet zonder belang voor de hier gevoerde bespreking, omdat de rechtbank Limburg, zoals hieronder zal blijken, in haar vonnis geen van de door de Hoge Raad geformuleerde aanwijzingen lijkt te hebben gebruikt.

\subsection{Beoordeling door de rechtbank Limburg}

\section{De verkeersopvatting}

De rechtbank Limburg noemt in haar vonnis - terecht - art. 3:4 BW uitdrukkelijk als de bepaling aan de hand waarvan het al dan niet hebben plaatsgehad van bestanddeelvorming dient te worden beoordeeld. ${ }^{16}$ De rechtbank schrijft:

'Is een bouwwerk bestanddeel van eens anders onroerende zaak, dan trekt dit bestanddeel na met die onroerende zaak. De horizontale natrekking prevaleert dan boven de verticale natrekking.'

De daaropvolgende zin, die de eerste van de volgende rechtsoverweging is, ${ }^{17}$ luidt echter:

'Wat als bestanddeel van een bouwwerk dient te worden aangemerkt, wordt bepaald door het in artikel 3:4 BW opgenomen verkeersopvattingcriterium (...).'

Die overgang is, althans vanuit theoretisch oogpunt, niet geheel zuiver. Eerst heeft de rechtbank het immers over een bouwwerk dat bestanddeel is van een zaak en vervolgens over iets dat bestanddeel is van een bouwwerk. Dat laatste is echter niet wat de rechtbank Limburg in deze zaak (finaal) dient te beoordelen. De te beantwoorden vraag is of de gangen onder perceel 2 bestanddeel zijn van perceel 1 of perceel 3, dus of een bouwwerk bestanddeel is van een zaak.

Wat de rechtbank Limburg hier waarschijnlijk bedoelt, is dat de beoordeling of de gangen onder perceel 2 bestanddeel zijn van het gehele gangenstelsel dient te gebeuren aan de hand van art. 3:4 BW. Niet veel verder in het vonnis brengt de rechtbank Limburg immers de hierboven reeds besproken eenheid tussen de gangen onder de verscheidene gronderven, die zij 'één zaak' noemt, ter sprake. Ook herformuleert zij daar de in deze zaak te beantwoorden vraag tot de vraag of de gangen onder perceel 2 bestanddeel zijn van het gehele gangenstelsel.

16. Rb. Limburg 7 februari 2018, ECLI:NL:RBLIM:2018:1142, r.o. 4.2.4. 17. Rb. Limburg 7 februari 2018, ECLI:NL:RBLIM:2018:1142, r.o. 4.2.4.
Gelet op de door de rechtbank Limburg bijgetreden zienswijze dat duurzaam verenigde gebouwen en werken bestanddeel van de grond zijn (zie hierboven), is dit, zoals gezegd, theoretisch niet geheel zuiver. Noch het gehele gangenstelsel, noch de gangen onder de percelen 1 en 3 zijn zaken, waardoor zij de gangen onder perceel 2 niet horizontaal kunnen natrekken. Het zijn daarentegen de percelen 1 en 3 die, daar zij zaken zijn, de gangen onder perceel 2 horizontaal zouden kunnen natrekken. Vanuit praktisch oogpunt valt de gedachtegang van de rechtbank echter perfect te begrijpen en ook bij te treden. De beoordeling of de gangen onder perceel 2 bestanddeel zijn van perceel 1 of perceel 3 verloopt immers onvermijdelijk via de gangen onder die gronderven, omdat die gangen, letterlijk zelfs, het enige aanknopingspunt tussen de gangen onder perceel 2 en de andere gronderven vormen. Als die gangen niet met elkaar zijn verbonden, kan er sowieso geen sprake zijn van horizontale natrekking ten behoeve van een ander gronderf.

\section{Onduidelijkheid omtrent de precieze grondslag voor de beslissing}

Aan de eigenlijke beoordeling of er in casu naar verkeersopvatting sprake is van bestanddeelvorming, besteedt de rechtbank Limburg weinig woorden. Noch het criterium van een constructieafstemming, noch het onvoltooidheidscriterium wordt (zichtbaar) toegepast en er wordt, waar de rechtbank overgaat tot de concrete beoordeling van het geschil, ook geen uitdrukkelijke melding meer gemaakt van de verkeersopvatting. De rechtbank beperkt zich tot het oordeel dat de gangen onder de verscheidene erven op elkaar aansluitende ondergrondse gangen zijn die toelaten om van het ene naar het andere gronderf te lopen en dus 'één zaak' vormen. ${ }^{18}$ Dat oordeel komt er behoorlijk snel en zonder (veel) toelichting.

Daarmee zit het werk van de rechtbank er nog niet op. De vaststelling dat objecten samen een geheel vormen, wordt onvermijdelijk gevolgd door de vraag welk van de verbonden objecten het geheel nu natrekt. Daarover oordeelt de rechtbank, zoals gezegd, dat perceel 1 de gangen onder perceel 2 horizontaal natrekt. Over de gangen onder perceel 3 zegt de rechtbank niets meer. Waarop de rechtbank Limburg die beslissing precies steunt, is niet volledig duidelijk. Nochtans is het vonnis op dit punt op het eerste gezicht duidelijk: ter beantwoording van de vraag wie eigenaar is van het gehele gangenstelsel, zo oordeelt de rechtbank Limburg, is het van (doorslaggevend) belang op welk perceel de hoofdingang van het gangenstelsel is gelegen'. ${ }^{19}$ Die duidelijkheid wordt echter tenietgedaan door het feit dat de rechtbank in de volgende zin focust op de onderlinge afstemming van de gangen onder de

18. Zie Rb. Limburg 7 februari 2018, ECLI:NL:RBLIM:2018:1142, r.o 4.2.6: 'Deze gangen houden (uiteraard) niet op bij de - eeuwen later vastgestelde - perceelgrenzen, maar lopen onder de verschillende percelen door en zijn met elkaar verbonden, waardoor het mogelijk is om ondergronds van het ene naar het andere perceel te lopen. De gangen onder voornoemde percelen vormen tezamen dan ook één gangenstelsel en daarmee één zaak.'

19. Rb. Limburg 7 februari 2018, ECLI:NL:RBLIM:2018:1142, r.o. 4.2.6. 
percelen 1 en 2 en zodoende op een andere beslissingsgrond lijkt over te stappen. ${ }^{20}$

Of is de rechtbank misschien van oordeel dat de hoofdingang is gelegen op het perceel waarvan de gangen een onderlinge afstemming vertonen met de gangen onder perceel 2, wat betekent dat zij de onderlinge afstemming ziet als een nadere invulling van het begrip 'hoofdingang'? Dat zou kunnen verklaren waarom de rechtbank vervolgt met de overweging '[h]oewel het gangenstelsel vanaf de openbare weg zowel via [perceelnummer 1] als via [perceelnummer 3] toegankelijk is'. Het lijkt er dus op dat de rechtbank, door op te merken dat er twee ingangen zijn, hier gaat onderzoeken op welk perceel nu de hoofdingang is gelegen. Daartegen kan worden ingebracht dat het enkele feit dat er tussen de gangen onder de percelen 1 en 2 een afstemming bestaat (wat hun inrichting en uitrusting betreft, zie infra), niet betekent dat de ingang op perceel 1 de hoofdingang is. Ook andere omstandigheden kunnen tot gevolg hebben dat een ingang als hoofdingang is te beschouwen, zoals zijn gebruiksfrequentie, specifieke ligging, gebruiksgemak en afmetingen.

De reeds meermaals genoemde onderlinge afstemming tussen de gangen onder de percelen 1 en 2, zo moet nog worden verduidelijkt, bestaat er volgens de rechtbank in dat in beide gangen nutsvoorzieningen zijn aangebracht en dat hun beider vloeren zijn gecementeerd en met vloerverwarming zijn uitgerust. Aan het einde van dezelfde rechtsoverweging geeft de rechtbank Limburg nog aan dat de afwezigheid van toestemming voor het aanbrengen van de vloerverwarming en het cement niet van belang is, omdat '[d]e beoordeling of een object bestanddeel is' aan de hand van objectieve maatstaven dient te gebeuren. Dit wekt de indruk dat de rechtbank Limburg haar oordeel inzake bestanddeelvorming voornamelijk heeft gesteund op de objectieve omstandigheid dat in beide gangen cement en vloerverwarming zijn aangebracht, eerder dan op de ligging van de hoofdingang tot het gangenstelsel. Volledig duidelijk is dit echter niet.

20. De gehele (relevante) passage uit het vonnis luidt (r.o. 4.2.6): 'Wie eigenaar van dit gangenstelsel is, dient te worden beantwoord aan de hand van verkeersopvattingen. Daarbij is het van (doorslaggevend) belang op welk perceel de hoofdingang van het gangenstelsel is gelegen (ECLI:NL:RBMAA:2000:AA5402). Hoewel het gangenstelsel vanaf de openbare weg zowel via [perceelnummer 1] als via [perceelnummer 3] toegankelijk is (2.2), is de eigenaar van perceel [perceelnummer 1], thans $J \& R(2.3)$, gezien de onderlinge afstemming van de gangen onder de percelen [perceelnummer 1] en [perceelnummer 2] tevens eigenaar van de gangen gelegen onder perceel [perceelnummer 2]. De vloeren in deze gangen onder deze percelen zijn voorzien van vloerverwarming, zijn gecementeerd en in de gangen onder beide percelen zijn nutsvoorzieningen aangebracht (2.5). De gangen onder [perceelnummer 2] worden (horizontaal) nagetrokken met perceel [perceelnummer 1].' Ook Visser lijkt in zijn annotatie bij het vonnis aan te nemen dat de rechtbank overgaat op een ander beoordelingscriterium, wanneer hij schrijft: 'De kantonrechter achtte het in dat verband van doorslaggevend belang op welk perceel de hoofdingang van het gangenstelsel is gelegen. Ook werd van belang geacht dat de vloeren in de gangen onder (...).' P.L. Visser, annotatie bij Rb. Limburg 7 februari 2018, ECLI:NL:RBLIM:2018:1142, TvZ 2018, p. 26 (curs. KS).

\section{Onderlinge afstemming}

Het gebruik van de woorden 'onderlinge afstemming' doet denken aan het eerder besproken criterium van het in constructief opzicht op elkaar afgestemd zijn van twee zaken. Het is echter weinig waarschijnlijk dat die associatie hier terecht en bedoeld is, onder meer omdat de woorden 'in constructief opzicht' niet voorkomen in het vonnis én omdat de rechtbank Limburg ook nergens verwijst naar de rechtspraak van de Hoge Raad of aangeeft dat het voornoemde criterium als beoordelingscriterium voor bestanddeelvorming geldt.

Bovendien is er in deze zaak mijns inziens geen sprake van een onderlinge afstemming in constructief opzicht als gevolg van de in de gangen uitgevoerde werken. Enkele voorbeelden van (de eerder schaarse) objecten die in de rechtspraak als in constructief opzicht op elkaar afgestemd werden bevonden, zijn: een zonwering en een appartementencomplex, bij de bouw waarvan in verregaande mate rekening werd gehouden met de montage, de bediening en het wegwerken van de zonwering, ${ }^{21}$ en een voor de geconditioneerde opslag van fruit bestemd bedrijfspand en de daarin geplaatste koel- en rijpcellen en stellages, waarbij uit de bouwtekeningen blijkt dat 'de afmetingen respectievelijk het aantal cellen en stellages, alsmede de omvang/afmetingen van het gebouw' op elkaar zijn afgestemd. ${ }^{22}$ Telkens gaat het om objecten waarbij al in de fase van hun constructie of vormgeving specifiek rekening werd gehouden met het andere object en de kenmerken (bijvoorbeeld afmetingen) daarvan. Daarvan is geen sprake bij de tunnels onder de percelen 1 en 2, waarin pas lang na hun constructie vloeren, vloerverwarming en nutsvoorzieningen werden aangebracht, wat louter ziet op de uitrusting of afwerking van de tunnels en niet op hun constructie. ${ }^{23}$ Hoogstens zou men kunnen betogen dat de gangen in constructief opzicht op elkaar zijn afgestemd doordat zij destijds zo werden uitgegraven, dat zij op elkaar aansluiten en een doorlopend gangenstelsel vormen. De uitgraving van een nieuw stuk gang werd met andere woorden beïnvloed door (bijvoorbeeld de ligging en afmetingen van) het daarvoor uitgegraven stuk gang. Die afstemming heeft echter niets te maken met de later aangebrachte vloeren, vloerverwarming en nutsvoorzieningen.

Het lijkt er dan ook op dat de rechtbank Limburg het criterium van afstemming in constructief opzicht, zoals geformuleerd door de Hoge Raad, niet heeft gebruikt en de onderlinge afstemming tussen de gangen onder de percelen 1 en 2 als een zelfstandige omstandigheid in aanmerking heeft genomen. Die

21. Hof Arnhem-Leeuwarden 8 januari 2019, ECLI:NL:GHARL:2019:69, r.o. 5.5 .

22. Hof Amsterdam 17 april 2018, ECLI:NL:GHAMS:2018:1600, r.o. 5.4.6.

23. Dat hier geen sprake is van een onderlinge afstemming in constructief opzicht, betekent echter niet dat hier geen sprake kan zijn van bestanddeelvorming. Zoals gezegd, heeft de Hoge Raad de aanwijzingen voor het bestaan van een positieve verkeersopvatting niet limitatief geformuleerd, zodat ook op grond van een andere omstandigheid dan onvoltooidheid of onderlinge afstemming in constructief opzicht naar verkeersopvatting sprake kan zijn van bestanddeelvorming. 
omstandigheid heeft zij niet zozeer in aanmerking genomen om te beoordelen of er bestanddeelvorming is, welke conclusie al vroeg in het vonnis wordt getrokken door te oordelen dat het gangenstelsel 'één zaak' vormt (zie hierboven), maar eerder om te beoordelen dat de bestanddeelvorming van de gangen onder perceel 2 met perceel 1 sterker is dan die met perceel 3 . Zowel perceel 1 als perceel 3 kwam in deze zaak immers in aanmerking om als hoofdbestanddeel ten aanzien van de gangen onder perceel 2 te worden aangemerkt, waardoor moest worden uitgemaakt welk perceel het meeste als hoofdbestanddeel kan worden aangemerkt. Anders verwoord, er moest worden bepaald met welk perceel de bestanddeelvorming het sterkste is. Algemeen wordt aangenomen dat ook die beoordeling aan de hand van de verkeersopvatting moet gebeuren. ${ }^{24}$

Hoewel dit niet uitdrukkelijk wordt vermeld in het vonnis, en daaruit ook niet met zekerheid kan worden afgeleid, bestaat er waarschijnlijk geen afstemming tussen de gangen onder de percelen 2 en 3, wat inderdaad een omstandigheid kan zijn die erop wijst dat in het verkeer eerder de gangen onder de percelen 1 en 2 dan die onder de percelen 2 en 3 als een geheel worden gezien. Die omstandigheid moet echter, zoals reeds werd toegelicht, in het geheel van de omstandigheden worden geplaatst, wat de rechtbank Limburg niet heeft gedaan, althans niet uitdrukkelijk. Een relevante omstandigheid zou bijvoorbeeld kunnen zijn dat het (substantieel) grootste gedeelte van het gangenstelsel onder een van de percelen is gelegen. ${ }^{25}$ Over hoe in casu de oppervlakte of lengte van het gangenstelsel verdeeld is over de verscheidene percelen zijn echter geen gegevens terug te vinden in het vonnis, behalve dat onder de percelen 1 en 3 niet alleen gangen, maar ook 'grote open ruimtes' zijn gelegen. ${ }^{26}$ De ligging van de hoofdingang kan eveneens, zoals hieronder wordt besproken, een relevante omstandigheid zijn.

\section{De ligging van de hoofdingang}

Bij de beoordeling van (mogelijke) horizontale natrekking wordt in rechtspraak en rechtsleer vaak belang gehecht aan op welk gronderf de ingang tot een grensoverschrijdend gebouw of werk is gelegen. ${ }^{27}$ In de mate dat het gebouw of werk slechts

24. Zie o.m. Ploeger 1997, p. 147; J.B. Spath, Horizontale natrekking en contractuele afspraken, ORP 2013, p. 30; Van der Plank 2016, p. 118; Visser 2018, p. 26.

25. Zie bijv. Hof Amsterdam 23 augustus 2011, ECLI:NL:GHAMS: 2011:BR6841, r.o. 4.8 en 4.12.

26. Rb. Limburg 7 februari 2018, ECLI:NL:RBLIM:2018:1142, r.o. 2.1.

27. Zie o.m. Hof 's-Hertogenbosch 2 mei 2017, ECLI:NL:GHSHE: 2017:1893; Hof Den Haag 14 september 2016, ECLI:NL:GHDHA: 2016:3024; Hof Amsterdam 23 augustus 2011, ECLI:NL:GHAMS: 2011:BR6841; Hof Arnhem 3 april 2001, ECLI:NL:GHARN: 2001:AD4258; Rb. Rotterdam 10 juli 2013, ECLI:NL:RBROT: 2013:6555; Rb. Utrecht 17 maart 2010, ECLI:NL:RBUTR: 2010:BL7867; Rb. Arnhem 26 mei 1998, ECLI:NL:RBARN: 1998:AH7588; Rb. Maastricht 6 april 2000, ECLI:NL:RBMAA: 2000:AA5402; Rb. Maastricht 13 juni 1996, ECLI:NL:RBMAA: 1996:AC3133. Zie ook o.m. M. Hoogesteger, Ondergronds ruimtegebruik, in het bijzonder in de Limburgse mergelgroeven, VGFC 2005, p. 6; Snijders \& Rank-Berenschot 2017, p. 464; Van der Plank 2016, p. 118-119; Visser 2018, p. 26-27. één ingang heeft, ${ }^{28}$ zou men dit criterium kunnen zien als een bijzondere toepassing van het eerder in dit artikel besproken onvoltooidheidscriterium, zij het in de omgekeerde richting. Zoals besproken, is iets een bestanddeel van een zaak op grond van het onvoltooidheidscriterium indien de zaak zonder dat iets onvoltooid is. Er wordt dus gekeken naar de onvoltooidheid van de zaak. Dat is anders bij het hier besproken criterium van de ligging van de enige ingang, waarbij wordt gekeken naar de onvoltooidheid van het (potentieel) bestanddeel, zijnde het gedeelte van het gebouw of werk dat is gelegen op het gronderf zonder ingang. Zonder ingang is dat gedeelte ontoegankelijk, kan het niet worden gebruikt, en kan het dus, vanuit functioneel oogpunt, onvoltooid worden genoemd, waardoor het goederenrechtelijk een geheel moet vormen met het gedeelte dat wel een ingang heeft (en dat in beginsel ook als hoofdbestanddeel van het geheel zal fungeren). Wanneer het grensoverschrijdende gebouw of werk echter, zoals in de casus die tot het vonnis van de rechtbank Limburg heeft geleid, meerdere ingangen heeft, is er geen link meer met het onvoltooidheidscriterium. Neemt men dan een van de ingangen weg, dan is het gebouw of werk nog steeds toegankelijk en te gebruiken, en dus niet onvoltooid.

Hoewel het criterium van de ligging van de ingang vaak wordt gebruikt of alleszins als beoordelingscriterium wordt genoemd, leert een blik op rechtspraak ${ }^{29}$ en rechtsleer ${ }^{30}$ dat het niet altijd doorslaggevend is en steeds in het ruimere geheel van de feiten en omstandigheden moet worden geplaatst. In een arrest van 23 augustus 2011 oordeelde het gerechtshof Amsterdam ${ }^{31}$ bijvoorbeeld, in tegenstelling tot wat de rechtbank Utrecht in eerste aanleg had geoordeeld, ${ }^{32}$ dat de enkele omstandigheid dat een gedeelte van (het restant van) een bunker enkel toegankelijk is via de ingang op een ander perceel, niet zonder meer meebrengt dat het wordt nagetrokken door het op dat andere perceel gelegen gedeelte. 'Onderzocht moet worden', zo verduidelijkt het hof, 'of naar verkeersopvatting deze gevolgtrekking in het onderhavige

28. Zie bijv. Rb. Rotterdam 10 juli 2013, ECLI:NL:RBROT:2013:6555; Rb. Maastricht 6 april 2000, ECLI:NL:RBMAA:2000:AA5402; Rb. Maastricht 25 maart 1999, ECLI:NL:RBMAA:1999:AS2691 (dat als tussenvonnis was gewezen in de zaak die tot het hiervoor geciteerde vonnis heeft geleid); Rb. Arnhem 26 mei 1998, ECLI:NL:RBARN: 1998:AH7588 (waarin echter niet tot horizontale natrekking werd besloten); Rb. Maastricht 13 juni 1996, ECLI:NL:RBMAA: 1996:AC3133.

29. Zie bijv. Hof Amsterdam 23 augustus 2011, ECLI:NL:GHAMS: 2011:BR6841; Hof Arnhem 3 april 2001, ECLI:NL:GHARN: 2001:AD4258, r.o. 4.9; Rb. Haarlem 23 april 2008, ECLI:NL:RBHAA: 2008:BD3214, r.o. 4.19; Rb. Arnhem 26 mei 1998, ECLI:NL:RBARN: 1998:AH7588.

30. Bijv. Ploeger schrijft: 'Toch kan de toegankelijkheid alleen niet beslissend zijn.' Zie Ploeger 1997, p. 148. Zie ook Visser 2018, p. 27.

31. Hof Amsterdam 23 augustus 2011, ECLI:NL:GHAMS:2011:BR6841.

32. Rb. Utrecht 17 maart 2010, ECLI:NL:RBUTR:2010:BL7867, r.o. 4.9. 


\section{Maandblad \\ Vermogensrecht}

geval gerechtvaardigd is. ${ }^{33} \mathrm{Bij}$ dat onderzoek kent het hof onder meer belang toe aan het feit dat het eerstgenoemde gedeelte van de bunker een zelfstandige gebruikswaarde heeft en dat, gelet op het te benutten vloeroppervlak in ieder gedeelte, niet gezegd kan worden dat het zwaartepunt van de bunker op één gedeelte ervan is gelegen, evenals aan het feit dat de bunker thans bestaat uit een aaneenschakeling van losse ruimtes die voor diverse doeleinden kunnen worden gebruikt en 'onderling geen logisch functioneel verband (meer) hebben'. ${ }^{34}$ Ter relativering van de omstandigheid dat de enige toegang tot de bunker op het andere perceel is gelegen, oordeelt het hof ook nog dat de eigenaar van dat andere perceel niet heeft bestreden dat het mogelijk is om op het eerste perceel alsnog een ingang tot het daarop gelegen gedeelte te creëren.

Ook blijkt de toepassing van het criterium van de ligging van de ingang soms tot het tegenovergestelde resultaat te leiden, namelijk dat de enige ingang of hoofdingang tot een gebouw of werk dit laatste niet horizontaal natrekt, maar daardoor horizontaal wordt nagetrokken. Zo werd geoordeeld dat een aanbouw, bestaande uit een ingang en hal, die als hoofdingang tot de op het aanpalende perceel gelegen winkel dient, een bestanddeel van dit perceel uitmaakt. ${ }^{35}$ In dezelfde zin werd geoordeeld dat een kleine constructie van zes vierkante meter die een trap bevat, bestanddeel is van een op het aanpalende perceel gelegen bovenwoning, omdat die constructie de enige toegang tot de bovenwoning vormt. ${ }^{36} \mathrm{Bij}$ de toepassing van het criterium van de enige ingang of hoofdingang moet dus steeds worden gekeken naar waar het zwaartepunt van de gehele grensoverschrijdende constructie is gelegen. Dit betekent dat, afhankelijk van de concrete omstandigheden van het geval, het criterium van de hoofdingang voor twee verschillende doeleinden kan worden gebruikt: enerzijds ter beantwoording van de vraag welk gedeelte van een grensoverschrijdende constructie daarvan het hoofdbestanddeel uitmaakt (en bijgevolg de gehele constructie horizontaal natrekt) en anderzijds ter beantwoording van de vraag of een aan- of bijbouw met ingang bestanddeel is van een grotere constructie op een aanpalend perceel (en bijgevolg daardoor horizontaal wordt nagetrokken).

Het gangenstelsel dat centraal stond in het vonnis van de rechtbank Limburg heeft meerdere ingangen. Bijgevolg kan het criterium van de enige ingang niet worden gebruikt om te bepalen ten behoeve van welk gronderf er horizontale natrekking is ingetreden en moet naar een ander criterium worden

33. Hof Amsterdam 23 augustus 2011, ECLI:NL:GHAMS:2011:BR6841, r.o. 4.7. Zie in dezelfde zin Hof Arnhem 3 april 2001, ECLI:NL:GHARN:2001:AD4258, r.o. 4.9: 'De enkele omstandigheid dat de tussenvloer slechts toegankelijk is via de dijkwoning brengt echter niet mee dat de tussenvloer als bestanddeel van de dijkwoning beschouwd dient te worden. Bezien dient te worden of de verkeersopvatting die gevolgtrekking rechtvaardigt.'

34. Hof Amsterdam 23 augustus 2011, ECLI:NL:GHAMS:2011:BR6841, r.o. 4.7.

35. Hof Arnhem-Leeuwarden 22 januari 2013, ECLI:NL:GHARL: 2013:BY9411.

36. Hof Den Haag 14 september 2016, ECLI:NL:GHDHA:2016:3024. gekeken. Dat heeft de rechtbank gedaan door de ligging van de hoofdingang als doorslaggevend aan te duiden. Daarbij verwijst de rechtbank naar een vonnis van de - toen nog - rechtbank Maastricht van 6 april 2000, ${ }^{37}$ wat echter enigszins opmerkelijk is, omdat in dat vonnis niet het criterium van de hoofdingang werd gehanteerd, maar dat van de enige ingang.

Eveneens opmerkelijk is dat de rechtbank Limburg het criterium van de hoofdingang vervolgens niet lijkt toe te passen op de feiten van het geval. Nergens in het vonnis geeft de rechtbank aan dat de hoofdingang tot het gangenstelsel op perceel 1 is gelegen of dat die niet op een van de andere percelen is gelegen. In deze zaak diende nochtans ook perceel 3 zich aan als een mogelijke kandidaat voor de titel van hoofdbestanddeel van de gangen, omdat ook op dat perceel een volwaardige toegang tot de gangen onder perceel 2 is gelegen. Evenmin wordt verduidelijkt welke kenmerken een ingang moet vertonen om als hoofdingang te kunnen worden gekwalificeerd of wordt enige toetsing in die zin uitgevoerd. De nadruk ligt daarentegen exclusief, op de eerder geciteerde zinsnede na, ${ }^{38}$ op de constructieve afstemming tussen de gangen onder de percelen 1 en 2 .

Wel spreekt de rechtbank Limburg zich uit over het door de erfpachter van perceel 2 aangevoerde argument dat de gangen onder dat perceel toegankelijk zijn via een volledig onder perceel 2 gelegen gang ('de verbindingsgang') die uitkomt in een ander bij de erfpachter in gebruik zijnd gangenstelsel, dat zich onder andere gronderven dan de percelen 1, 2 en 3 lijkt te bevinden, en bijgevolg daardoor wordt nagetrokken. De rechtbank oordeelt dat dit argument niet kan slagen, onder meer omdat de verbindingsgang niet uitkomt op een (openbare) weg, maar aansluit op een ander gangenstelsel. ${ }^{39}$ Het precieze gewicht van deze omstandigheid in het oordeel van de rechtbank is echter niet duidelijk, omdat de rechtbank haar in één zin combineert met de omstandigheid dat het gangenstelsel al eeuwen bestaat en de verbindingsgang pas later is ontstaan. Daardoor is niet duidelijk hoeveel belang de rechtbank aan elk van deze omstandigheden hecht.

Met de tweede omstandigheid doelt de rechtbank, zo lees ik het vonnis, op het feit dat er al lang voordat de verbindingsgang werd gegraven horizontale natrekking (van de gangen onder perceel 2) ten behoeve van een naburig perceel kan hebben plaatsgehad. Die redenering is correct, maar men mag niet uit het oog verliezen dat de gevolgen van bestanddeelvorming niet in steen gebeiteld staan zodra op enig moment bestanddeelvorming heeft plaatsgehad. Het is niet uitgesloten dat zich op een later tijdstip een fysieke of functionele wijziging voordoet die tot gevolg heeft dat een bestanddeel ophoudt een bestanddeel te zijn van de zaak waarvan het tot dan toe bestanddeel uitmaakte, bijvoorbeeld doordat een horizontaal

37. Rb. Maastricht 6 april 2000, ECLI:NL:RBMAA:2000:AA5402.

38. Zie de tweede alinea onder het kopje 'Onduidelijkheid omtrent de precieze grondslag voor de beslissing' in deze paragraaf.

39. Rb. Limburg 7 februari 2018, ECLI:NL:RBLIM:2018:1142, r.o. 4.2.7. 
nagetrokken (gedeelte van een) gebouw of werk fysiek wordt afgesloten van het gronderf waardoor het horizontaal werd nagetrokken (bijvoorbeeld door een doorgang af te sluiten of een muur op te trekken). Ook kan worden gedacht aan een grensoverschrijdend gebouw of werk met één ingang dat op enig ogenblik op zodanige wijze op het andere erf een ingang krijgt, dat in het verkeer voortaan (het gedeelte op) het andere erf als hoofdbestanddeel van het geheel wordt beschouwd. Vanzelfsprekend staat die omstandigheid niet op zichzelf. Bij de beoordeling of het gebouw of werk is opgehouden een bestanddeel te zijn, welke beoordeling ook moet worden gemaakt in het an de rechtbank Limburg voorgelegde geschil, ${ }^{40}$ moet rekening worden gehouden met het geheel van de omstandigheden. Mogelijk relevante omstandigheden zijn bijvoorbeeld de dreigende incompleetheid van de onroerende zaak, waarvan het gebouw of werk tot op heden een bestanddeel was, de constructieve afstemming op deze laatste, de mate waarin het geheel waarvan het gebouw of werk deel uitmaakt overwegend onder het ene dan wel het andere erf is gelegen, ${ }^{41}$ en enige andere omstandigheid die in het kader van de verkeersopvatting relevant is. Blijkt het gebouw of werk geen bestanddeel meer te zijn van de zaak waarvan het dat voordien wel was, dan vindt mijns inziens, net zoals bij het einde van een opstalrecht, de uitzondering op de basisregel van de verticale natrekking, zijnde horizontale natrekking, geen toepassing meer en wordt het gebouw of werk verticaal nagetrokken. Dit alles geldt uiteraard op voorwaarde dat het gebouw of werk inmiddels geen bestanddeel van een andere onroerende zaak (dan het erf waarop het zich bevindt) is geworden en thans daardoor horizontaal wordt nagetrokken.

\section{Mede-eigendom in plaats van verticale natrekking?}

\subsection{Verticale natrekking als basisregel in situaties van onbeslechte horizontale natrekking}

De feiten die aanleiding hebben gegeven tot het vonnis van de rechtbank Limburg vormen een mooi opstapje naar de bespreking van de problematiek van onbeslechte horizontale natrekking. Daarmee doel ik, zoals eerder aangegeven, op situaties waarin een grensoverschrijdend bouwwerk volgens de verkeersopvatting een geheel vormt, maar meerdere onroeren-

40. Onder meer naar aanleiding van het graven van de verbindingsgang.

41. Bartels lijkt hier bijv. belang aan te hechten, waar hij als voorbeeld van een situatie van onbeslechte horizontale natrekking een bouwsel noemt dat vanaf beide percelen toegankelijk is en 'zich ook min of meer voor gelijke delen op elk der percelen' bevindt. S.E. Bartels, Een grensoverschrijdende treurwilg, AA 2011, p. 639. Zie ook Hof Amsterdam 23 augustus 2011, ECLI:NL:GHAMS:2011:BR6841, waarin onroerende natrekking onder meer om de volgende reden niet werd aangenomen (r.o. 4.8): 'Gelet op het te benutten (netto) vloeroppervlak in de op de beide percelen gelegen bunkerdelen, zoals af te leiden uit de afmetingen die op de plattegrond staan vermeld, kan niet zonder meer worden gezegd dat het zwaartepunt van het bunkerrestant op het ene dan wel het andere perceel ligt.' En verderop (r.o. 4.12): 'Het gaat hier om een bunkerrestant dat zich over twee percelen uitstrekt, zonder dat gezegd kan worden dat het zwaartepunt van dat bunkerrestant op het ene of het andere perceel rust.' Ploeger staat echter kritisch tegenover 'de maatstaf van de meetlat'. Zie Ploeger 1997, p. 148. de zaken als het hoofdbestanddeel daarvan zouden kunnen worden aangemerkt. ${ }^{42}$ Het gaat met andere woorden om situaties waarin meerdere onroerende zaken quasi even sterk aan het geheel trekken. Daarbij kan bijvoorbeeld worden gedacht aan een brug die twee gronderven met elkaar verbindt en (uitsluitend) op elk van deze gronderven steunt, of aan een grensoverschrijdende kelder, schuur of gang die vanaf beide gronderven toegankelijk is en zich voor min of meer gelijke delen op beide percelen bevindt. ${ }^{43}$

In dergelijke situaties is het bijzonder moeilijk tot onmogelijk om het pleit in het voordeel van één onroerende zaak, en dus ook in het nadeel van een andere onroerende zaak (of andere onroerende zaken), te beslechten. Het lijkt erop dat men dan, bij gebreke van een duidelijke uitzondering daarop (in de vorm van horizontale natrekking), moet terugvallen op de basisregel van art. 5:20 lid 1 sub e BW en ten behoeve van ieder gronderf verticale natrekking moet laten plaatsvinden met betrekking tot het daarop of daarin aangebrachte gedeelte. Voor alle duidelijkheid, de reden waarom hier geen horizontale natrekking plaatsvindt, is niet dat er volgens de verkeersopvatting geen sprake is van een geheel, want daarvan is wel degelijk sprake, maar wel dat de verkeersopvatting onbeslist is over welk gronderf het hardste aan het geheel trekt.

\subsection{Mede-eigendom in situaties van onbeslechte horizontale natrekking?}

\section{Mede-eigendom van het grensoverschrijdende werk of gebouw}

Sommige auteurs pleiten voor een andere oplossing, die er concreet in bestaat dat in situaties van onbeslechte horizontale natrekking het grensoverschrijdende werk of gebouw het voorwerp van een (goederenrechtelijke) gemeenschap gaat uitmaken. ${ }^{44}$ De achterliggende gedachte daarbij is dat de eenheid die het werk of de constructie over de perceelsgrenzen heen vormt, behouden moet blijven en moet prevaleren boven de verticale natrekking. De gevormde eenheid zou immers verloren gaan wanneer men ten behoeve van ieder gronderf verticale natrekking zou laten intreden, omdat de verschillende delen van het werk of gebouw dan onderscheiden eigenaars zouden hebben. Zoals Bartels terecht opmerkt, houdt die oplossing in dat er naast de eigendomsrechten op de gronder-

42. Ter anduiding van het (gronderf waarop het) hoofdbestanddeel (is gelegen) wordt ook wel de term 'het kernperceel' gebruikt. Zie bijv. Hof 's-Gravenhage 30 december 2011, ECLI:NL:GHSGR: 2011:BV1499, r.o. 8.1.4; Hof 's-Gravenhage 27 december 2011, ECLI:NL:GHSGR:2011:BV1489, r.o. 8.2; Ploeger 1997, p. 147; Van der Plank 2016, p. 118; Visser 2018, p. 26. Spath heeft het dan weer over het gronderf waarop 'het zwaartepunt' van de grensoverschrijdende opstal zich bevindt. Spath 2013, p. 30.

43. Deze voorbeelden zijn ontleend aan Bartels 2011, p. 639. Zie eerder echter ook al Ploeger 1997, p. 152, en specifiek m.b.t. het voorbeeld van de brug: K.F.M. Berger, Wie is eigenaar van de kerkbrug in Schipluiden?, WPNR 1995, afl. 6206, p. 883-884; Snijders \& Rank-Berenschot 2017, p. 240.

44. Zie bijv. Asser/Bartels 5 2017/82a; Bartels 2011, p. 639; Berger 1995, p. 884; Ploeger 1997, p. 152-153. 
ven een afzonderlijk eigendomsrecht op het werk of gebouw komt te bestaan. ${ }^{45}$ De betrokken grondeigenaars hebben dan enerzijds een eigendomsrecht op hun gronderf en anderzijds een aandeel in de mede-eigendom op het werk of gebouw.

Een wettelijke grondslag voor die oplossing is echter niet (direct) voorhanden in het BW, dat enkel verticale natrekking en horizontale natrekking kent als mogelijke uitkomst bij het duurzaam verbinden van een werk of gebouw met de grond. $\mathrm{Zij}$ vindt echter wel, zo wordt betoogd, ${ }^{46}$ steun in rechtspraak van de Hoge Raad, volgens welke een boom die met zijn stam op de perceelsgrens staat, in mede-eigendom toebehoort aan de eigenaars van de betrokken gronderven. ${ }^{47}$ Daarbij moet echter worden opgemerkt, zo erkennen de betrokken auteurs zelf ook, dat een dergelijke boom, althans naar de letter van de wet, geen vragen van horizontale natrekking doet rijzen, omdat in art. 5:20 lid 1 sub e in fine BW enkel sprake is van 'gebouwen of werken' die bestanddeel zijn van de onroerende zaak van een ander en een boom noch een gebouw, noch een werk is. Ook wordt, ter staving van de mede-eigendomsoplossing, gewezen op de wettelijke mandeligheid uit art. 5:62 BW, die eveneens het bestaan van twee eigendomsrechten en een tussen de eigenaars gedeeld derde eigendomsrecht (op een afzonderlijke zaak) tot gevolg heeft. ${ }^{48}$ In de voornoemde bepaling is echter enkel sprake van scheidsmuren, hekken en heggen, waardoor de wettelijke mandeligheid wat betreft haar voorwerp beperkt is.

\section{Relativering van de mede-eigendomsoplossing}

De mede-eigendomsoplossing verdient zonder twijfel de voorkeur wanneer het gaat om een boom die met zijn stam op de perceelsgrens staat, omdat anders 'niet te scheiden delen van dat object afzonderlijk zouden worden nagetrokken' ${ }^{49}$ en zodoende een onwenselijke en praktisch moeilijk werkbare situatie zou worden gecreëerd. ${ }^{50}$

Moet echter ook voor mede-eigendom worden gekozen bij een gebouw of werk dat zich in een situatie van onbeslechte horizontale natrekking bevindt? Mijns inziens verdient de medeeigendomsoplossing in een dergelijk geval niet zonder meer de voorkeur. Of tot mede-eigendom dan wel verticale natrekking moet worden besloten, hangt af van de specifieke omstandigheden van het geval. Gaat het bijvoorbeeld om een brug die twee gronderven met elkaar verbindt en enkel op die gronderven steunt, dan zou het laten intreden van verticale natrekking, net zoals bij de grensoverschrijdende boom, tot een onwenselijke en praktisch soms moeilijk werkbare situatie kunnen leiden. Bij andere werken of constructies echter ont-

45. Bartels 2011, p. 638.

46. Zie Asser/Bartels 5 2017/82a; Bartels 2011, p. 639.

47. Zie HR 20 mei 2011, ECLI:NL:HR:2011:BP9997; HR 3 mei 1996, ECLI:NL:HR:1996:ZC2060 (Huizing/Andere Woonvormen).

48. Zie Asser/Bartels 5 2017/82a; Bartels 2011, p. 639; Ploeger 1997, p. 153.

49. Bartels 2011, p. 638

50. Van Maanen schrijft eveneens dat deze situatie onwenselijk is: G.E. van Maanen, De boom van Bartels, NTBR 2012/2, afl. 1, p. 3. breekt in beginsel die manifeste nood aan het niet laten intreden van verticale natrekking en kunnen andere overwegingen mogelijk zwaarder doorwegen. Het behoud van wat fysiek of functioneel een eenheid vormt, is weliswaar een belangrijke overweging, maar de eerbiediging van het exclusieve eigendomsrecht van de grondeigenaar is dat evenzeer. Hoewel hij als gevolg daarvan ook mede-eigenaar wordt van een gedeelte van een gebouw of werk van een ander, heeft de mede-eigendomsoplossing immers tot gevolg dat een grondeigenaar geen exclusieve eigenaar is van een werk of constructie waarvan hij normaliter, uit hoofde van zijn eigendomsrecht op de grond en art. 5:20 lid 1 sub e BW, wel exclusieve eigenaar zou zijn. Ook heeft deze oplossing tot gevolg dat de wettelijke regels inzake gemeenschap (art. 3:166 e.v. BW) moeten worden nageleefd. Uit die regels vloeien voor de deelgenoten onder meer beperkingen voort wat betreft het gebruik, het beheer en het genieten van de vruchten van de gemeenschappelijke zaak.

Gelet op deze beperkingen alsmede op het feit dat de wetgever verticale natrekking als basisregel heeft ingesteld en de medeeigendomsoplossing daarop een uitzondering vormt zonder een (directe) wettelijke basis, mag in situaties van onbeslechte horizontale natrekking niet te snel tot het bestaan van medeeigendom worden besloten. Als de verscheidene gedeelten van een gangenstelsel bijvoorbeeld afzonderlijk (voldoende) toegankelijk zijn, functioneel en eventueel ook fysiek te scheiden zijn (bijvoorbeeld door middel van een scheidingswand) en, misschien wel in de eerste plaats, zinvol afzonderlijk kunnen worden gebruikt, ${ }^{51}$ dan moet, gelet op het geheel van de omstandigheden, mijns inziens eerder tot verticale natrekking dan tot mede-eigendom worden besloten. Dit geldt niet alleen voor gangen, eventueel inclusief de gangen van het vonnis van de rechtbank Limburg, ${ }^{52}$ maar in beginsel voor elke grensoverschrijdende constructie (bijvoorbeeld een kelder, loods, bunker, schuur of kruipruimte) die aan de voornoemde vereisten voldoet en zich in een situatie van onbeslechte horizontale natrekking bevindt.

\section{Conclusie}

Uit de bovenstaande bespreking is gebleken dat het antwoord op de vraag of iets horizontaal wordt nagetrokken vaak het volgens menig niet-jurist typische antwoord van een jurist zal zijn, namelijk 'dat hangt ervan af. Hoe frustrerend een derge-

51. Vgl. bijv. met Rb. Den Haag 14 maart 2018, ECLI:NL:RBDHA: 2018:3001, r.o. 4.21 en met het hiervoor besproken oordeel van het gerechtshof Amsterdam (23 augustus 2011, ECLI:NL:GHAMS: 2011:BR6841) in de zaak over het grensoverschrijdende bunkerrestant, waarin horizontale natrekking onder meer werd afgewezen op de grond dat beide gedeelten een zelfstandige gebruikswaarde hebben. Wel moet worden opgemerkt dat het hof in deze zaak ook heeft geoordeeld dat er geen sprake meer was van een functionele eenheid tussen beide gedeelten van het bunkerrestant, wat mogelijk anders is bij bijv. een grensoverschrijdende (ondergrondse) gang, kelder of schuur.

52. Op voorwaarde dat de gangen naar verkeersopvatting een geheel vormen met meer dan één gronderf en meer dan één gronderf als hoofdbestanddeel zou kunnen worden aangemerkt. Anders verwoord: op voorwaarde dat er in deze zaak sprake is van een situatie van onbeslechte horizontale natrekking, wat afhangt van het geheel der omstandigheden en de verkeersopvatting. 


\section{Maandblad}

lijk antwoord ook mag zijn, bij horizontale natrekking heeft de jurist geen andere keuze. Of er sprake is van horizontale natrekking moet immers worden beoordeeld aan de hand van de verkeersopvatting, wat onvermijdelijk betekent dat rekening moet worden gehouden met het geheel van de omstandigheden. Afhankelijk van de specifieke omstandigheden van het geval zal in het verkeer immers anders over de verbinding tussen twee (of meer) objecten worden gedacht, zo ook bij horizontale natrekking.

In dit artikel werden, met veelvuldige terugkoppeling naar een interessant vonnis van de rechtbank Limburg van 7 februari 2018, de theorie en basisprincipes inzake horizontale natrekking uiteengezet en werd bijzondere aandacht besteed aan situaties van onbeslechte horizontale natrekking. Dat zijn situaties waarin er meer dan één onroerende zaak is die een grensoverschrijdend gebouw of werk, dat naar verkeersopvatting een geheel vormt, horizontaal zou kunnen natrekken. In verband daarmee heb ik geconcludeerd dat medeeigendom zeker een oplossing kan zijn, maar dat die oplossing met de nodige terughoudendheid moet worden toegepast. De voornaamste argumenten daarvoor zijn dat verticale natrekking het door de wetgever gekozen uitgangspunt is inzake duurzaam met de grond verenigde werken en gebouwen, er voor de mede-eigendomsoplossing geen (directe) wettelijke basis bestaat, en die oplossing bovendien tot gevolg heeft dat een grondeigenaar die normaliter de exclusieve eigenaar van een (gedeelte van een) gebouw of werk zou zijn, zich plots beperkt ziet door de regels inzake de gemeenschap. 